Cowan, S. T. (1956). J. gen. Microbiol. 15, 345-358

\title{
Taxonomic Rank of Enterobacteriaceae 'Groups'
}

\author{
By S. T. COWAN
}

National Collection of Type Cultures, Colindale Avenue, London, N.W. 9

\begin{abstract}
SUMMARY: The taxonomic value of the different 'groups' into which the Enterobacteriaceae are divided is assessed, and consideration is given to the classification of different groups within the family. No scheme fits the requirements of all workers and two different approaches are made, one for workers in applied bacteriology, and a more logical one for taxonomic purists. For the former scheme it is suggested that common (vulgar) names should be used to describe the groups and their subdivisions. Linnaean binomials are essential for the more systematic scheme, in which the Arizona group is merged with Salmonella; Ballerup-Bethesda is combined with Citrobacter freundii; Sonne's bacillus and Bacillus alcalescens are included in Escherichia; Cloaca and Hafnia (32011) are included as species of Klebsiella, and Providence (29911) as a species of Proteus. Few of these suggestions are new, but the scheme is a classification of a family and not a collection of 'groups'.
\end{abstract}

In taxonomic studies it is convenient to divide organisms into groups and subgroups, leaving the status of rank for each category to be decided when order appears and the work is nearing completion. Problems of rank are met with in all types of organism; they are attacked in different ways in different disciplines, but even in one branch of microbiology there is no uniformity. Among bacteria certain organisms from the intestines of animals present special problems; their morphological and cultural characters are alike, and resemble those of bacteria found in soil, in water and on plants. Though there is nothing to be said in favour of an ecological grouping of bacteria, in practice ecology may determine the primary grouping: a plant pathologist studies those bacteria found in plants, the water bacteriologist studies essentially similar organisms in water, and the clinical pathologist finds them in human or animal excretions. Often these ecologists work in isolation and develop independent taxonomic schemes.

White (1937), writing on the construction of a taxonomic system for bacteria, contrasted determinative keys with systems based on mutual relations and differences. He said that such a system must develop from multiple foci of intensive study, which would gradually widen until they became confluent; only then could an opinion be formed as to the rational groupings of larger size. Of necessity such a system would be built slowly, but it would be laid on sure foundations. White himself laid many of these foundations and, with Kauffmann, Jordan, St John-Brooks, Schütze and Scott of the original Salmonella Subcommittee, paved the way by making an intensive study of one group of organisms. Since then the number of groups studied has increased, and the Salmonella Subcommittee of the International Committee on Bacteriological Nomenclature has been replaced by an Enterobacteriaceae Subcommittee (E.S.) which covers many more of the 'multiple foci'. Enlarging 
the foci has, as White forecast, resulted in their confluence, and the time seems ripe for an assessment of what are 'rational groupings'.

\section{Subdivisions of the ENTERobacteriaceae}

Taxonomic ranks are based on the number of shared characters; higher ranks have few characters in common, lower ranks have many, so that the finest subdivisions, or lowest ranks, may be distinguished by only one or two differences. Intensive study of the enteric bacteria has resulted in the use of minute differences to characterize the various subdivisions, but there remains a lack of uniformity of criteria used in characterization of the different ecological groups. Thus the plant pathogens have been studied along the time-honoured lines of morphology and fermentative ability with little study of their serology or of the characters revealed by the newer tests for deaminases and decarboxylases; the water bacteriologists have concentrated their attention on tests to distinguish between so-called 'faecal coli' and those forms believed to have a different source; while the clinical bacteriologists have, until recently, relied largely on antigenic analysis.

The Enterobacteriaceae Subcommittee (Report, 1954a) define the family as Gram-negative non-sporing rods, either motile with peritrichate flagella or non-motile, which grow on ordinary media and ferment glucose rapidly, with or without gas production; nitrates are reduced to nitrites. The Subcommittee (Report, 1954a, b) recognizes nine groups, Salmonella, Shigella, Arizona, Escherichia, Alkalescens-dispar, Klebsiella, Bethesda, Proteus, Providence, but does notimply that these should be regarded as genera. Kauffmann(1953)would make further subdivisions and add as groups, presumably of equivalent rank, Cloaca, Morganella and Rettgerella. Møller (1954) created another group which he named Hafnia. To these should be added Erwinia (and perhaps Pectobacterium) and the Prodigiosus group (reasons for not using the name Serratia are given in Cowan, 1956). Even these groups do not include all the enteric bacteria, and the common lactose-fermenting motile forms with IMViC reactions --++ , which fail to liquefy gelatin, have no place in the scheme.

It seems to me that the 'groups' mentioned are not of equal taxonomic rank, and that it would be profitable to consider what rank should be accorded to each. With this in mind I have drawn up a table which shows the majority reactions of different groups in both the old and newer type of biochemical test (Table 1). Some of the 'groups' shown in Table 1 differ slightly from similar groups of the Enterobacteriaceae Subcommittee Reports; for example Escherichia freundii is shown separately and is not included with either the Escherichia group or the Bethesda-Ballerup group. In recording reactions the Salmonelia group is shown as gas-producing; this is the reaction of the majority of serotypes, but of course it does not imply that all anaerogenic strains should be classified as Salmonella typhi. In the same way Klebsiella pneumoniae is shown as VP-positive, although a small proportion of strains is vP-negative.

Before discussing the groups in detail it will be convenient to fix the taxonomic ranik of one, to which the others can be referred. Escherichia, which is based on Escherichia coli, would be the group of choice, but the picture is 
Providence $+\theta+101011 \pm+11_{1}|+1+| 1 \mid++\theta 1+$

Proteus rettgeri $+1+++1+1+\pi+1 * 110++111+++1+$

P. morganii $+++1|1| 1|1| 1 \mid 1+1+1+ ++ \pm 1+++11+$

P. mirabilis $t++1|1| 1|1| 1+1++\theta+++1 \quad 1+++11+$

P. vulgaris $+++1|1| 1|1|++++1+++|1|++\theta 1+$

Hafnia $t+++1|1| 1 \mid 0 \times 11++11++ \pm+1+t+1$

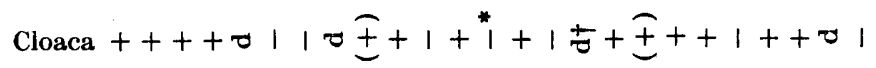

K. pneumoniae $1++++0+++1\left|1^{*}\right|+1+++1 \mid 1+++1$

K. rhinoscleromatis $11+++1+1++1|1|+1+1|1|+1+1$

Klebsiella ozaenae $10+++1+ \pm+\times 11^{*} 11+x+1011++11$

Bethesda-Ballerup $++++|\sigma \times x=011+1+x+1+01++| 1$

ischerichia freundii $++++|\sigma x+\sigma| 1+1+1+|+| 1++\infty 1$

Other shigellas $11+0101|1| \nabla|1|+1+1+1+1|1|$

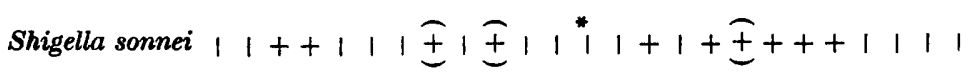

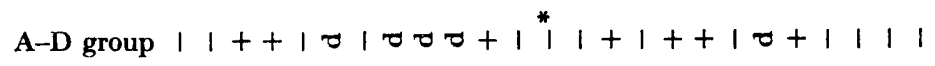

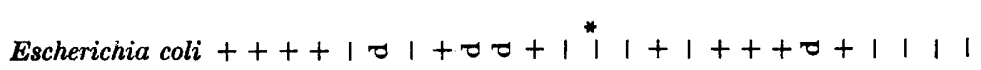

Arizona ++++111 王 111 王 $+1+1++++11++1$

Other salmonellas $++++1+01|1| 1|+1+1++++11+1|$

Salmonella typhi $+1++1 \times 1|1| 1|1|+1+1+++1|1| 1|1|$

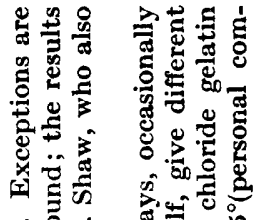

它记

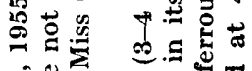

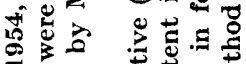

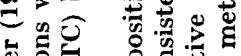

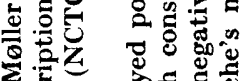

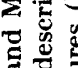

要

政

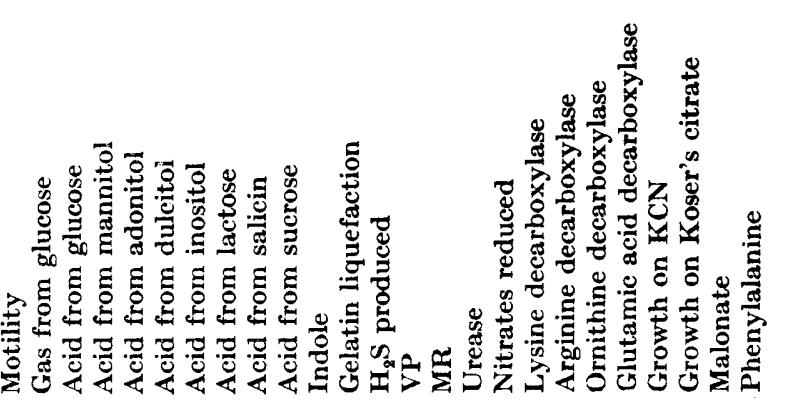


complicated by the fact that although the Enterobacteriaceae Subcommittee (Report, 1954b), Kauffmann (1954), and Edwards \& Ewing (1955) separate $E$. freundii from the Escherichia group, they retain the generic name Escherichia for the species and thus make it appear that the group is an emasculated genus. I shall discuss the Escherichia group presently, and for the moment would prefer to fix the taxonomic rank of the Salmonella group. Most bacteriologists now look upon this group as a genus (see, for example, Bergey's Manual, 1948; Topley and Wilson's Principles, 1955), and it can, without difficulty, be given generic rank. Therefore, in the sequel, I shall assume that the Salmonella group forms the basis of a genus, Salmonella.

\section{Salmonella and Arizona groups}

In the Salmonella group Salmonella typhi is in a class of its own; its constant anaerogenic habit and its lack of ornithine decarboxylase distinguish it from the other motile salmonella species or serotypes. Most of the aerogenic salmonellas share a biochemical pattern; this is similar to that of Arizona strains, except that the latter liquefy gelatin, ferment lactose slowly, and do not ferment dulcitol. The malonate test distinguishes Arizona strains from the more typical salmonellas, but some gelatin-liquefying salmonellas (e.g. $S$. dar-essalaam) are, like Arizona strains, malonate-positive (Shaw, 1956), and thus form a link. Antigenic overlapping is so great that Salmonella diagnostic antisera can be used as substitutes for many of the Arizona antisera (Edwards \& Ewing, 1955). As Seligmann \& Saphra (1951) and Edwards \& Ewing (1955) pointed out, the allocation of some strains to Salmonella or Arizona is quite arbitrary, and the problem is to decide whether the Arizona group is equivalent in rank to Salmonella or only to part of Salmonella.

The Enterobacteriaceae Subcommittee Reports of 1950 and 1953 (Report $1954 a, b)$ describe Salmonella and Arizona separately, and this arrangement is followed by Kauffmann (1954) and by Edwards \& Ewing (1955). However, this usage has become established because it is more convenient to have two antigenic schemes than to combine them. It seems to me that in a systematic classification the Arizona group is equivalent only to a part of the Salmonella group, of which it should be regarded as a major subdivision, equivalent in rank, vis à vis other salmonellas, to Salmonella typhi, i.e. to a species. The species thus created, Salmonella arizonae, is divisible into the serotypes of the Arizona group.

The nomenclatural problems of Salmonella are complex. The name Salmonella received official recognition when the Salmonella Subcommittee was appointed (Report, 1937). The acceptance by the Salmonella Subcommittee (1934) of $S$. cholerae-suis as type species created difficulties that were not foreseen at the time. With increasing knowledge of the permutations and combinations of antigens of the group there is less willingness to regard each combination as a species; these are now viewed as serotypes of a relatively small number of species. Three solutions of the nomenclatural difficulty present themselves: (i) all aerogenic salmonellas can be named $S$. chloreae-suis and individuals distinguished by subspecific epithets or numbers; (ii) the aerogenic 
salmonellas can be divided into two species as suggested by Borman, Stuart \& Wheeler (1944) and by Kauffmann \& Edwards (1952); (iii) each combination of antigens, or serotypes, can be given a common name, as Salmonella London. The difficulty arises because of the necessity to report Salmonella spp. or serotypes in such a way that their significance will be apparent to a number of people with different professional backgrounds. To a clinician the name $\boldsymbol{S}$. cholerae-suis var. paratyphi-B would be extremely confusing, as would $S$. cholerae-suis var. pullorum to a veterinarian. Fortunately the needs of the clinician, veterinarian, medical officer of health, sanitary inspector and general practitioner can be met by the use of common rather than scientific names. This is in fact the procedure at present adopted, though the use of italic type and lower-case initial letter for the place name gives the false impression of a specific binomial. For the systematist the suggestions of Borman et al. (1944) and of Kauffmann \& Edwards (1952) provide the better solution; in considering these proposals it should be borne in mind that the epithet kauffmannii has priority over enterica.

\section{Escherichia and Alkalescens-dispar $(\boldsymbol{A}-\boldsymbol{D})$ groups}

The Escherichia group, as defined in Enterobacteriaceae Subcommittee Reports, consists of organisms classified as Escherichia coli and its varieties, including E. coli-mutabile and anaerogenic strains. Although the fermentation of lactose is regarded as a main character of the species $E$. coli it is not requisite for inclusion in the Escherichia group (Kauffmann, 1954). Should $E$. coli be limited to strains which ferment lactose promptly, another species would have to be designated for the slow fermenters or non-fermenters of lactose that have other characters of the Escherichia group; such a species was defined and named Paracolobactrum coliforme by Borman et al. (1944).

The Escherichia group, based on Escherichia coli and including both lactosefermenters and non-fermenters, clearly forms a group of rank equal to the salmonellas. It remains to be decided: (i) whether a species is justified for the late or non-lactose-fermenters; (ii) whether there are species from other groups to be transferred to the genus Escherichia.

Kauffmann (1954) would not exclude non-lactose fermenters from Escherichia coli, and indeed several strains of his serotypes do not ferment the sugar; the Enterobacteriaceae Subcommittee (Report, 1954 $a, b$ ) also supports the inclusion of the non-lactose fermenting strains. At the present time there is not enough evidence that the lactose fermenters differ significantly from the non-fermenters to justify creating a species based on Paracolobactrum coliforme (Borman et al. 1944), but, as in all these problems, future work may demand a change in outlook.

A whole 'group' to be included in the genus Escherichia is the Alkalescensdispar (A-D) group, composed of anaerogenic, non-motile organisms with $\mathbf{O}$ and $\mathrm{K}$ antigens of the Escherichia group. The recognition of one or two species within this group depends on the importance placed on lactose fermentation; dispar is a lactose-fermenter (prompt or delayed) and alkalescens does not ferment lactose, but there are many strains difficult to assign to one or other 
species; it is, therefore, advisable to combine them, as in the Subcommittee's Reports. Bacillus alkalescens and $\boldsymbol{B}$. dispar were both described and named in the same paper (Andrewes, 1918) and priority, decided by the order of their appearance, makes alkalescens, changed to alcalescens in conformity with the accepted views on transliteration, the correct specific epithet for the combined species. Information on the biochemical reactions of the A-D group is scanty, and I have not found a paper describing their decarboxylases; those observed in a limited number of strains by Miss C. Shaw are shown in Table 1. It is convenient to draw attention here to Sonne's bacillus (Shigella sonnei), the indole-negative biochemical counterpart of Bacillus dispar; its decarboxylases, except for a quantitative difference in lysine production, are the same as those of Escherichia coli, and differ from those of the other Shigella species or serotypes. The biochemical and serological characters of Sonne's bacillus are similar to those of the motile coliform C27 (Ferguson \& Henderson, 1947; Schmid, Velaudapillai \& Niles, 1954), and it seems logical that it should be regarded as an Escherichia species, but neither C27 nor Sonne's bacillus has any of the Escherichia $O$ antigens 1-130 (Edwards \& Ewing, 1955).

Thus, while the transfer of Sonne's organism to the genus Escherichia is logical and probably desirable systematically, it is hardly practicable as its membership of the Shigella group has become so firmly established. Furthermore, its inclusion in the genus Escherichia would be opposed by those who regard the Shigella group not as a bacteriological entity but as the dysentery group of bacteria (Bensted, 1956). However, if ever bacterial systematics are aliowed to become logical, this is one of the transfers that could profitably be made, and $I$ have made it in the systematic scheme at the end of this paper.

\section{Shigella group}

The other Shigella spp. form a homogeneous group related to the Escherichia group both by biochemical and serological reactions. Their decarboxylase activities are often weak, but the pattern of all shigellas, except Sonne's bacillus, is indistinguishable (Moller, 1954). Many shigella serotypes cross-react with escherichia antisera (Ewing, 1953; Edwards \& Ewing, 1955) but the majority have, in addition, specific antigens by which they can be recognized, and which justify the genus Shigella. It is debatable whether $S$. boydii should be a distinct species or a variety of $S$. flexneri; the serotypes of $S$. flexneri are not biochemically homogeneous and except by serology cannot be distinguished from $S$. boydii; it is probably more systematic to recognize two varieties of $S$. flexneri, namely var. flexneri and var. boydii.

The removal of Sonne's bacillus from Shigella leaves that genus as a group of organisms divided biochemically into two subgroups, but this subdivision based on mannitol fermentation is not without exception; Ewing has found mannitolfermenting strains of $S$. dysenteriae serotype 3, and non-mannitol-fermenting strains of $S$. flexneri serotypes 1-6, and of $S$. boydii serotypes 3 and 6 (Ewing, 1954; Edwards \& Ewing, 1955). In a personal communication, Ewing suggests that any revision of shigella classification should combine all existing species. 
The modification of the Enterobacteriaceae Subcommittee's (Report, 1954a) classification of shigellas proposed in the fourth edition of Topley and Wilson's Principles (1955) is likely to increase confusion; in this three species are recognized in the non-mannitol fermenting subgroup $A$, and one of them, the Large-Sachs group, is named $S$. ambigua, a name previously attached to Schmitz's bacillus.

Shigella nomenclature has been the subject of an Official Opinion (no. 11) of the Judicial Commission (1954). For the taxonomic scheme suggested here for systematists, there are only two species and Sonne's bacillus is transiated to Escherichia. However, it is realized that neither clinicians nor clinicai pathologists would welcome this improvernent in its systernatic position, and for their specialized use the name $S$. sonnei would be retained.

\section{Bethesda-Ballerup and freundii group}

The Enterobacteriaceae Subcommittee (Report, 1954b) regard the Bethesda group as the slow lactose-fermenting counterpart of the indole-negative cultures classified as Escherichia freundii, and include both lactose fermenters and non-fermenters in the 'Bethesda (Bethesda-Ballerup) group'. Kauffinann (1954) used the same arrangement but designated the group as a species, 'Escherichia freundii (including Bethesda-Ballerup)'. The decarboxylases of the group are unlike those of the Escherichia group, and in these, as in the KCN test, the reactions of the group more closely resemble those of the Klebsiella group. The lactose fermenters form the two species Citrobacter freundii and C. intermedium (Werkman \& Gillen, 1932), distinguished mainly by $\mathrm{H}_{2} \mathrm{~S}$ production; under suitable conditions both are $\mathrm{H}_{2} \mathrm{~S}$-positive (Clarke, 1953) and I have combined them in Table 1. Antigenic overlapping between the Escherichia serotypes and Escherichia freundii seems to be unusual, but a Bethesda strain related to Escherichia serotype 0111:B4 has been described (Ørskov, Schmid \& Velaudapillai, 1953). Kauffmann (1954), in his table 1, shows $E$. freundii as a species of Escherichia, but in his table 3, which is based on the KCN test and decarboxylases, it is grouped with Klebsiella, Cloaca and Hafnia, all of which are $\mathrm{KCN}$ positive and can use citrate as a carbon source; in these characters they differ from $E$. coli. There seems to be good reason for including $E$. freundii in the Bethesda group, and for excluding the combined group from Escherichia, according it equal (i.e. generic) rank with that group (Kauffmann, 1953). This solution raises a minor problem of nomenclature best disposed of here: $\boldsymbol{E}$. freundii is a synonym of Citrobacter freundii (Braak) Werkman \& Gillen (1932), and this name antedates Bethesda ballerupensis Kauffmann \& Edwards (1952) and Bethesda freundii (Kauffmann, 1953). Consequently, the generic name valid for the group is Citrobacter Werkman \& Gillen, and the types species is Citrobacter freundii. The Bethesda-Ballerup organisms, which are slow or non-fermenters of lactose, could correctly be given the name Citrobacter ballerupensis Kauffmann \& Edwards, nov.comb., aithough such a segregation of lactose fermenters and non-lactose fermenters is not consistent with the policy developed so far in this classification. 


\section{Klebsiella, Cloaca and Hafnia groups}

The Klebsiella group is primarily divided by differences in the capsular antigens. Motile forms are excluded (Report, 1954b), but neither Kauffmann (1954) nor Edwards \& Ewing (1955) regard this as a satisfactory solution of a difficult problem. Edwards \& Fife (1955) found that 19 motile strains gave Quellung reactions with klebsiella antisera; 17 of these strains liquefied gelatin and all had the general biochemical reactions of the 128 motile strains studied. Edwards (Edwards \& Ewing, 1955; Edwards \& Fife, 1955) would redefine the genus Aerobacter with Aerobacter cloacae as the type species; I shall discuss this proposal presently.

If, for the moment, we restrict our consideration to the non-motile forms (i.e. the Klebsiella group of the ES reports) the majority of strains are aerogenic and have the $\mathrm{IMViC}$ reactions --++ , but there is a sufficiently large proportion of anaerogenic strains, and strains with different IMViC reactions (Ørskov, 1955) to suggest that the group might be divided on the basis of these reactions. The aerogenic --++ forms consist of strains which are typical of Aerobacter aerogenes and of Friedländer's bacillus (Klebsiella pneumoniae) and, as these cannot be distinguished either by biochemical or serological tests, (Report, 1954b) they are now usually considered together, often without species designation (Kauffmann, 1953, 1954; Edwards \& Ewing, 1955; Edwards \& Fife, 1955). It will be less confusing to say at once that if we accept the Klebsiella group as a genus, these aerogenic --++ organisms form a species whose correct name is probably Klebsiella pneumoniaecrouposae (Zopf) nov.comb. (see Cowan, 1954) but which has become well established as Klebsiella pneumoniae, by which name I shall refer to it here.

Strains with other IMViC reactions are distributed among many capsule serotypes but are especially frequent in types 1, 2, 3, 4 and 5; Edwards \& Fife (1955) found 81 of 173 strains of these serotypes were MR-positive, VPnegative, and of these 52 of 59 were types 4 and 5 . It is not easy to determine from published data the distribution of anaerogenic strains among the different serotypes; for strains of known serotypes examined in this Collection (NCTC) the frequency was as follows:

Serotype
1
$\mathbf{2}$
3
4
5
6

Aerogenic
$\mathbf{9}$
15
7
17
8
9

Anaerogenic
$\mathbf{2}$
$\mathbf{3}$
$\mathbf{6}$
$\mathbf{3}$
$\mathbf{0}$
$\mathbf{0}$

Serotype 3 anaerogenic strains have other characters which segregate them from other klebsiella strains (Goslings, 1934), and these undoubtedly represent Klebsiella rhinoscleromatis, which can be described as citrate-negative, lactosenegative, malonate-positive and lysine-negative, whereas the aerogenic strains of type 3 are lactose-positive and lysine-positive.

Klebsiella ozaenae, represented by types D, E and F of Goslings \& Snijders 
(1936), or types 4, 5 and 6 in the newer terminology, are either aerogenic or anaerogenic, MR-positive, VP-negative, citrate-positive and malonate-negative.

The motile strains with $\mathrm{IMViC}$ reactions --++ may or may not liquefy gelatin. In describing Bacillus cloacae, Jordan (1903) reported that all strains were actively motile, that most liquefied gelatin slowly, that 14 of 21 strains fermented lactose, but often this was slow. Kauffmann $(1953,1954)$ would resurrect the genus Cloaca, Castellani \& Chalmers (1919), for these organisms, but Edwards \& Fife (1955) prefer to redefine Aerobacter, basing it on a new type A. cloacae. Another possibility not considered by these authors is to make the motile forms, both liquefying and non-liquefying, a species of Klebsiella, i.e. Klebsiella cloacae (Jordan) nov.comb., and this is what I propose to do here. This has the advantage that motile and liquefying strains which react with klebsiella capsule antisera can be typed as Klebsiella species, whereas it would be confusing to describe a strain as Cloaca cloacae Klebsiella type $\mathbf{X}$, or Aerobacter cloacae Klebsiella type Y. Unfortunately this kind of designation has sometimes to be made to describe certain antigenic overlaps, e.g. some strains of Escherichia coli have salmonella antigens.

Stuart's 32011 type (Stuart, Wheeler, Rustigian \& Zimmerman, 1943; Stuart \& Rustigian, 1943) forms part of the species Paracolobactrum aerogenoides (Borman et al. 1944) and falls within the Hafnia group of Møller (1954) with the type species Hafnia alvei (Bahr) Møller. These bacteria resemble Klebsiella pneumoniae in being IMViC,$--++ \mathrm{KCN}$-positive, malonate-positive and having a strong lysine decarboxylase; they differ in being motile, lactose-negative, urease-negative and having an ornithine and a weak arginine decarboxylase. They also resemble the Cloaca group (K. cloacae), of which they might be considered the non-lactose fermenting, gelatin-negative counterpart. Eventually the Cloaca and Hafnia groups may be combined, but for the moment I propose to regard Hafnia as a species of Klebsiella, with the name $K$. alvei (Bahr) nov.comb. Thus, I have arranged the motile - - + + forms in two species, $K$. cloacae and $K$. alvei, differing mainly on the fermentation of lactose. There are forms which are gelatin-positive and lactose-negative, by Jordan's circumscription these are regarded as $\boldsymbol{K}$. cloacae, as are the gelatinnegative, lactose-positive motile forms. Consideration was given to the possibility of creating another species for the gelatin-negative, lactose-positive form but as the gelatin liquefaction test must have an arbitrary time limit and is greatly influenced by the type of gelatin used and the method of sterilization (Report, 1956 b), such a new species would be based on much too flimsy grounds and there would be a likelihood that strains would drift from $K$. cloacae to the new species as they gradually lost their gelatin-liquefying power on subculture.

\section{Proteus and Providence groups}

Within recent years the genus Proteus has been defined with urease production as the main diagnostic character (Rustigian \& Stuart, 1945; Cook, 1948). However, Proteus species are not the only members of the Enterobacteriaceae to produce urease; many strains of Klebsiella spp., and some strains of Escherichia and Citrobacter spp. are urease-positive. A more specific distinguishing 
character is the ability of Proteus spp. to deaminate phenylalanine (Henriksen, 1950). The test, originally described by Henriksen \& Closs (1938), is one of the simplest of biochemical tests and, among the Enterobacteriaceae, is positive only in the Proteus and Providence groups.

Fulton (1943) proposed that Morgan's No. 1 bacillus should be made the type of a new genus Morganella, a suggestion repeated by Kauffmann (1953) together with the removal of Rettger's bacillus from Proteus and the creation of a new genus Rettgerella. Kauffmann (personal communication) still prefers to separate Morgan's and Rettger's bacilli from Proteus, but in his book (Kauffmann, 1954) he does not press this solution. Proom \& Woiwod (1951) would not only remove Rettger's bacillus from Proteus but Proom (1955) would combine it with the Providence group. On the other hand, several workers (Singer \& Bar-Chay, 1954; Buttiaux, Osteux, Fresnoy \& Moriamez, 1954; Shaw \& Clarke, 1955) have pointed to the relation between Providence and Proteus cultures, although only a few Providence cultures are urease-positive. Buttiaux et al. (1954) and Shaw \& Clarke (1955) made formal proposals that the Providence group, which is the 29911 type of Stuart (Stuart et al. 1943; Stuart, Wheeler \& McGann, 1946), should be included in the genus Proteus. Buttiaux et al. (1954) proposed the very appropriate name $\boldsymbol{P}$. stuartii, but Shaw \& Clarke (1955) found that a culture of Bacillus inconstans belonged to this group and this strain probably represented the oldest described species of what is now the Providence group. The inclusion of the Providence group in the genus Proteus subordinates the urease to the phenylalanine test, a test which, among the Enterobacteriaceae, is specific for the five species of Proteus as circumscribed here.

The Prodigiosus group consists of those peritrichously flagellated Gramnegative rods which produce a pink or red pigment; several species are described but the criteria on which species separation is made are of doubtful value. Dr F. Hormaeche drew my attention to the fact that in biochemical tests many of these organisms resemble the Cloaca group. Finally the plant pathogens have not been considered and have been left out of Table 1 as so little is known of their biochemical reactions; aerogenic strains have, in general, the characters of the Cloaca group, but the anaerobic strains are more distinctive.

\section{CONCLUSIONS}

This discussion of the classification and nomenclature of the enteric bacteria clearly shows that a logical and systematic classification would not adequately fill the needs of those who work with this group. These specialists are handling cultures sent to them by bacteriologists in certain applied fields, as clinical pathology and water bacteriology, and the reports of the specialists must be readily understood by an even greater variety of people, some of whom have little or no biological background. Thus, there is unfortunately a need for two classifications, one scientific, the other applied.

The taxonomic scheme on which a scientific classification is based is always subject to change as additional knowledge is gained, and this may be reflected 
by changes in nomenclature. To the applied scientist such changes are anathema and it is, therefore, better that he should use a scheme that can easily be modified without a consequent change of nomenclature. This can be best done by using common (or vulgar) names for the bacteria being classified; unfortunately many of these common names have some semblance to the Linnaean binomials used in a systematic scheme. The simplest common nomenclature is based on aetiology or ecology, for example, "the typhoid bacillus' or 'faecal-coli', but, except for pathogens, the plan rapidly breaks down. A compromise has to be made, as in the scheme for coliform bacteria (Report, 1956a) in which latinized binomials are used; some, as Escherichia coli and Citrobacter freundii, are nomenclaturally correct but others, as Klebsiella aerogenes, are a compromise between the usage of water bacteriologists and the correct $K$. pneumoniae-crouposae.

Most of this paper has been concerned with the scientific scheme which attempts to systematize the classification of these organisms, and this is summarized in the third column of Table 2 . The other scheme must be a

Table 2. Correlation of classification and nomenclature of: (1) reports of the Enterobacteriaceae Subcommittee; (2) a compromise scheme for applied bacteriology; (3) a scheme for the taxonomic purist

E.S. Reports

Salmonella

Arizona
Escherichia
Alkalescens-Dispar
or A-D group
Shigella

Shigella

Bethesda

Escherichia freundii

Klebsiella

Cloaca
Hafnia
Proteus

Providence
Compromise scheme

Salmonella typhi (typhoid bacillus)

S. cholerae-suis (hog cholera bacillus)

S. typhi-murium (mouse typhoid bacillus)

Salmonella London

Arizona + serotype or antigenic formula

Escherichia coli

Alcalescens-dispar (or A-D)+ serotype

Shigella sonnei (Sonne's bacillus)

S. dysenteriae $\left\{\begin{array}{l}\text { Shiga's bacillus } \\ \text { Schmitz's bacillus } \\ \text { Large-Sachs' bacilli }\end{array}\right\}$

S. flexneri (Flexner's bacilli)

S. boydii (Boyd's bacilli)

Bethesda ballerupensis)

Citrobacter freundii

Klebsiella pneumoniae

Klebsiella + serotype

$\boldsymbol{K}$. aerogenes (water bacteriology)

Cloaca cloacae

Hafnia alvei or 32011 group

Proteus vulgaris

P. mirabilis

P. morganii (Morgan's bacillus)

P. rettgeri (Rettger's bacillus)

Providence + serotype or 29911 group

\section{Systematist's scheme}

Salmonella typhi

S. cholerae-suis

S. kauffmannii var. typhimurium

S. kauffmannii var. London

S. arizonae + serotype

Escherichia coli

E. alcalescens

E. sonnei.

Shigella dysenteriae

S. flexneri var. flexneri

S. flemeri var. boydii

Citrobacter freundii

Klebsiella pneumoniae

$\{\boldsymbol{K}$. rhinoscleromatis

K. ozaenae
K. cloacae
$\boldsymbol{K}$. alvei
Proteus vulgaris
P. mirabilis
$P$. morganii
$P$. rettgeri
$P$. inconstans 
compromise and need not be good systematics. Although it would be difficult to improve on the detail of its Reports $(1954 a, b)$, the Enterobacteriaceae Subcommittee has never published a comprehensive classification. The first column of Table 2 shows the groups of the E.S. Reports, and the second column shows a slight re-arrangement which occupies, I think, a position midway between the working groups of the Subcommittee and the systematist's genera and species. Thus, in the compromise scheme, organisms of the Salmonella group would be known and reported as Salmonella typhi, S. paratyphi-B, or Salmonella London, the last preferably with an initial capital for the place name and printed in roman. Until the antigenic scheme for the Arizona group is fully integrated with the Salmonella group it will be convenient to retain the two. The only major divergence from the nomenclature used by the E.S. Reports concerns the subgroup named Escherichia freundii; these organisms are clearly different from the $E$. coli and it would be wiser to adopt now the nomenclaturally correct, Citrobacter freundii. In the Klebsiella group, a subgroup or species Klebsiella aerogenes is suggested for organisms isolated by water bacteriologists, who would create considerable confusion and dismay among the public if they reported a human pathogen (K. pneumoniae or Friedländer's bacillus) in a potable water supply. The Cloaca and Hafnia groups are not further subdivided, and, in this scheme, Providence is separated from Proteus.

Applied bacteriologists are not willing to be treated as chaff and blown hither and thither at every change in taxonomic breeze, and it is our duty to recognize them as the producers of seed which provides us, the taxonomic purists, with our plants for further study.

This paper owes any merits it possesses to a series of discussions with many bacteriologists, to all of whom I want to express my thanks; they include Lt.-Col. H. J. Bensted, Brigadier J. S. K. Boyd, Dr R. E. Buchanan, Dr K. P. Carpenter, Dr P. R. Edwards, Dr W. H. Ewing, Dr E. Hormaeche, Dr F. Kauffmann, Miss Constance Shaw, Dr Joan Taylor, Dr E. Windle Taylor and Dr G. S. Wilson. For the views expressed here I am alone responsible.

\section{REFERENCES}

Andrewes, F. W. (1918). Dysentery bacilli: the differentiation of the true dysentery bacilli from allied species. Lancet, $\mathrm{i}, \mathbf{5 6 0}$.

Bensted, H. J. (1956). Dysentery bacilli-Shigella. A brief historical review. Canad. J. Microbiol. 2, 163.

Bergey's Manual of Determinative Bacteriology (1948). 6th ed. Edited by Breed, R. S., Murray, E. G. D. \& Hitchens, A. P. London: Baillière, Tindall and Cox.

Borman, E. K., Stuart, C. A. \& Wheeler, K. M. (1944). Taxonomy of the family Enterobacteriaceae. J. Bact. 48, 351.

Buttiaux, R., Osteux, R., Fresnoy, R. \& Moriamez, J. (1954). Les propriétés biochimiques caractéristiques du genre Proteus. Inclusion souhaitable des Providencia dans celui-ci. Ann. Inst. Pasteur, 87, 375.

Casteldani, A. \& Chalmers, A. J. (1919). Manual of Tropical Medicine, 3rd ed. p. 958. London: Baillière, Tindall and Cox.

Clarke, P. H. (1953). Hydrogen sulphide production by bacteria. J.gen. Microbiol. $8,397$. 
Cook, G. T. (1948). Urease and other biochemical reactions of the Proteus group. J. Path. Bact. 60, 171.

Cowan, S. T. (1954). A review of names for coliform organisms. Int. Bull. bact. Nom. Tax. 4, 119.

Cowan, S. T. (1956). 'Ordnung in das Chaos' Migula. Canad. J. Microbiol. 2, 212.

Edwards, P. R. \& Ewing, W. H. (1955). Identification of Enterobacteriaceae. Minneapolis: Burgess Publishing Co.

Edwards, P. R. \& Fife, M. A. (1955). Studies on the Klebsiella-Aerobacter group of bacteria. J. Bact. 70, 382.

EwING, W. H. (1953). Serological relationships between Shigella and coliform cultures. J. Bact. 66, 333.

Ewing, W. H. (1954). Mannitol negative varieties of Shigella flexneri serotypes. J. Immunol. 72, 404.

Ferguson, W. W. \& Henderson, N. D. (1947). Description of strain C27 : a motile organism with the major antigen of Shigella sonnei phase I. J. Bact. 54, 179.

Fulton, MAcD. (1943). The identity of Bacterium columbensis Castellani. J. Bact. 46, 79.

GosLings, W. R. O. (1934). Untersuchungen über das Scleroma respiratorium (Sklerom). II. Mitteilung: Die biochemisch-kulturellen Eigenschaften der Skleromstämme im Vergleich mit den anderen Kapselbakterien. Zbl. Bakt. (1. Abt. Orig.), 133, 33.

Goslings, W. R. O. \& SniJders, E. P. (Printed as Gastings \& Snijders) (1936). Untersuchungen über das Scleroma respiratorium (Sklerom). IV. Mitteilung. Die antigene Struktur der Skleromstämme im Vergleich mit den anderen Kapselbakterien. Zbl. Bakt. (1. Abt. Orig.), 136, 1.

Henriksen, S. D. (1950). A comparison of the phenylpyruvic acid reaction and the urease test in the differentiation of Proteus from other enteric organisms. J. Bact. 60, 225.

Henriksen, S. D. \& Closs, K. (1938). The production of phenylpyruvic acid by bacteria. Acta path. microbiol. scand. 15, 101.

Jordan, E. O. (1903). The kinds of bacteria found in river water. J. Hyg., Camb. 3, 1.

Judicial Commission (1954). Opinions 4, 6, 7, 8, 9, 10, 11, 12, 13, 14. Int. Bull. bact. Nom. Tax. 4, 141.

KaUfFMANN, F. (1953). On the classification and nomenclature of Enterobacteriaceae. Riv. Ist. sieroter. ital. 28, 485.

Kauffmann, F. (1954). Enterobacteriaceae, 2nd ed. Copenhagen: Ejnar Munksgaard.

Kauffmann, F. \& EDwards, P. R. (1952). Classification and nomenclature of Enterobacteriaceae. Int. Bull. bact. Nom. Tax. $2,2$.

Kauffmann, F., Edwards, P. R. \& Ewing, W. H. (1956). The principles of group differentiation within the Enterobacteriaceae by biochemical methods. Int. Bull. bact. Nom. Tax. 6, 29.

Møller, V. (1954). Distribution of amino acid decarboxylases in Enterobacteriaceae. Acta path. microbiol. scand. 35, 259.

Møller, V. (1955). Simplified tests for some amino acid decarboxylases and for the arginine dihydrolase system. Acta path. microbiol. scand. 36, 158.

Ørskov, F., Schmid, E. E. \& Velaudapillai, T. (1953). An Escherichia freundii strain related to Escherichia coli 111:B4. Acta path. microbiol. scand. 32, 565.

Ørskov, I. (1955). The biochemical properties of Klebsiella (Klebsiella aerogenes) strains. Acta path. microbiol. scand. 37, 353.

Proom, H. (1955). Amine production and nutrition in the Providence group. J. gen. Microbiol. 13, 170.

Proom, H. \& Worwod, A. J. (1951). Amine production in the genus Proteus. J. gen. Microbiol. 5, 930.

Report (1937). Nomenclature Committee, 1936. II Congr. int. Microbiol. London, 543. 
Repont (1954a). The Enterobacteriaceae Subcommittee of the Nomenclature Committee of the International Association of Microbiologists. Reports of the Enterobacteriaceae Subcommittee on the groups Salmonella, Shigella, Arizona, Bethesda, Ballerup, Escherichia, Alkalescens-Dispar, Klebsiella, and Proteus in Rio de Janeiro, August, 1950. Int. Bull. bact. Nom. Tax. 4, 1.

R.Port $(1954 b)$. The Enterobacteriaceae Subcommittee of the Nomenclature Committee of the International Association of Microbiologists. Reports of the groups: Salmonella, Shigella, Arizona, Bethesda, Escherichia, Klebsiella (Aerogenes, Aerobacter), Providence (29911 of Stuart et al.). Int. Bull. Bact. Nom. Tax. 4, 47.

Report (1956a). The Society for Applied Bacteriology. The nomenclature of coliaerogenes bacteria. Report of the Coli-aerogenes (1956) Subcommittee. J. Appl. Bact. 19, 108.

REPORT (1956b). The Standardization Subcommittee of the Society for General Microbiology. Constituents of Bacteriological Culture Media. Cambridge University Press.

Rustigian, R. \& Stuart, C. A. (1945). The biochemical and serological relationships of the organisms of the genus Proteus'. J. Bact. 49, 419.

Salmonella Subcommitee of the Nomenclature Committee of the InterNational Society for Microbiolocy (1934). The genus Salmonella Lignières, 1900. J. Hyg., Camb. 34, 333.

Schmid, E. E., Velaudapillat, T. \& Niles, G. R. (1954). Study of paracolon organisms with the major antigen of Shigella sonnei, form I. J. Bact. 68, 50.

Seligmann, E. \& Saphra, I. (1951). An unusual enteric pathogen. Pub. Hlth Rep. 66, 1369 .

Shaw, C. (1956). Distinction between Salmonella and Arizona by Leifson's sodium malonate medium. Int. Bull. bact. Nom. Tax. 6, 1.

Shaw, C. \& Clarke, P. H. (1955). Biochemical classification of Proteus and Providence cultures. J. gen. Microbiol. 13, 155.

Singer, J. \& Bar-Chay, J. (1954). Biochemical investigation of Providence strains and their relationship to the Proteus group. J. Hyg., Camb. 52, 1.

Stuart, C. A. \& Rustigian, R. (1943). Further studies on one type of paracolon organism. Amer. J. publ. Hlth, 33, 1323.

Stuart, C. A., Wheeler, K. M. \& McGanN, V. (1946). Further studies on one anaerogenic paracolon organism, type 29911. J. Bact. 52, 431.

Stuart, C. A., Wheeler, K. M., Rustigian, R. \& Zimmerman, A. (1943). Biochemical and antigenic relationships of the paracolon bacteria. J. Bact. 45, 101.

Topley and Wilson's Principles of Bacteriology and Immunity (1955). 4th ed. Revised by Wilson, G. S. \& Miles, A. A. London: Edward Arnold (Publishers) Ltd.

Werkman, C. H. \& Gillen, G. F. (1932). Bacteria producing trimethylene glycol. J. Bact. 23, 167.

White, P. B. (1937). Remarks on the nomenclature and classification of bacteria. II Congr. int. Microbiol. London, p. 547.

(Received 20 April 1956) 